\title{
Benthic macroinvertebrates of a tropical lake: Lake Caçó, MA, Brazil
}

\author{
Lucca, JV. ${ }^{\mathrm{a}}$, Pamplin, PAZ. ${ }^{\mathrm{b}}$, Gessner, AF. ${ }^{\mathrm{c}}$, Trivinho-Strixino, $\mathrm{.}^{\mathrm{c}}$ \\ Spadano-Albuquerque, $A L .{ }^{\mathrm{d}}$ and Rocha, $O{ }^{\mathrm{a}}$ \\ a'Departamento de Ecologia e Biologia Evolutiva, Universidade Federal de São Carlos - UFSCar, \\ Rod. Washington Luís, Km 235, CEP 13565-905, São Carlos, SP, Brazil \\ 'Instituto de Ciência e Tecnologia, Universidade Federal de Alfenas - UNIFAL, \\ Campus Poços de Caldas, CEP 37701-970, Poços de Caldas, MG, Brazil \\ 'Departamento de Hidrobiologia, Universidade Federal de São Carlos - UFSCar, \\ Rod. Washington Luís, Km 235, CEP 13565-905, São Carlos, SP, Brazil \\ ${ }^{\mathrm{d}}$ Departamento de Geoquímica, Instituto de Química, Universidade Federal Fluminense - UFF, \\ Outeiro São João Batista, s/n, $5^{\circ}$ andar, Centro, CEP 24020-015, Niterói, RJ, Brazil \\ *e-mail: fjvlucca@ufscar.br \\ Received November 11, 2008 - Accepted June 18, 2009 - Distributed August 31, 2010
}

(With 2 figures)

\begin{abstract}
Benthic communities are highly relevant in the study of aquatic ecosystems, both for their role in the functioning of the ecosystem and also as markers or indicators of paleo-conditions. Their distribution, as in other communities, is conditioned by abiotic and biotic factors and to their interactions, which determine the structure of the community that is established. The aim of this study was to determine the taxonomic composition, abundance and spatial distribution of the benthic community, by collecting at 20 sampling sites in Caçó Lake (State of Maranhão, Brazil). Seasonal variation in these community parameters was analysed and related to the seasonal displacement of the Intertropical Convergence Zone. The results indicated that changes occur in the taxa richness, diversity and density of the benthic species of this lake that are mainly related to seasonality. All those parameters were higher in the dry than in the rainy period. The family Chironomidae (Diptera, Insecta) was the most important component of the community, representing approximately $50 \%$ of the total benthic fauna of the lake. The identification of the Chironomidae currently occurring in Lake Caçó is relevant, even at the genus level, considering the fact that this group produces fossilizing remains and could perhaps be good paleolimnological and paleoclimatic tracers that could be used to make inferences on past lake and climate conditions.
\end{abstract}

Keywords: benthic community, Chironomidae, Lake Caçó, tropical Limnology, macroinvertebrates.

\section{Macroinvertebrados bentônicos de um lago tropical: lago Caço, MA, Brasil}

\section{Resumo}

As comunidades bentônicas são relevantes nos ecossistemas aquáticos devido ao seu papel no seu funcionamento e também como marcadores ou indicadores de paleocondições. Sua distribuição, similarmente à de outras comunidades, é condicionada por fatores abióticos e bióticos e pela interação entre eles, determinando a estrutura da comunidade que se estabelecerá.

O objetivo do presente trabalho foi determinar a composição taxonômica, a abundância e a distribuição espacial da comunidade bentônica, amostrando-se em 20 pontos na lagoa do Caçó (Estado do Maranhão, Brasil). As variações sazonais nas características desta comunidade foram analisadas e relacionadas ao deslocamento sazonal da Zona de Convergência Intertropical. Os resultados indicaram que ocorrem mudanças na riqueza de taxons, diversidade e densidade da comunidade bentônica deste lago que são principalmente relacionadas à sazonalidade. Todas as variáveis analisadas foram maiores no período seco do que no chuvoso. Os organismos pertencentes à família Chironomidae (Diptera, Insecta) foram os mais importantes componentes da comunidade, representando aproximadamente $50 \%$ do total da fauna. A identificação dos Chironomidae atualmente presentes no Lago Caçó, mesmo em nível de gênero, é relevante, considerando-se o fato de que as larvas deste grupo produzem remanescentes fósseis que podem ser bons traçadores paleolimnológicos e paleoclimáticos, podendo ser utilizados para fazer inferências sobre as condições passadas neste lago e no clima regional.

Palavras-chave: comunidade bentônica, Chironomidae, Lago Caçó, limnologia tropical, macroinvertebrados. 


\section{Introduction}

Despite its recognised ecological importance, the benthic community is still one of the least known communities in tropical freshwaters (Jackson and Sweeney, 1995; Parsons and Norris, 1996). However, on account of their importance in ecological processes, studies on these communities in Brazilian waters have noticeably gained importance (Nessimian, 2005; Davanso and Henry, 2007; Strixino and Trivinho-Strixino 1998; Callisto et al., 1998; Moreno and Callisto, 2006; Gonçalves et al., 2007; Fidelis et al., 2008; Henry and Santos, 2008).

Benthic organisms actively participate in the energy flow and nutrient cycles within aquatic ecosystems, having a major role in the exchange of phosphorus and nitrogen between the sediment and the water (Gardner et al., 1983; Fukuhara and Sakamoto, 1988; Leal et al., 2003,
Pelegri and Blackburn, 1996, Real et al., 2000). By constantly turning the sediment, through their digging and tunnelling activity, and by breaking down the solid organic matter that settles there, these organisms reduce the size of particles and this contributes to the liberation of nutrients trapped in the sediment, into the water column (Marques et al., 1999; Callisto and Esteves, 1998). They also form part of the food chain of diverse important aquatic animals, notably fish (Margalef, 1983) and have a relevant role in the recovery of organic matter and nutrients for the water column by bioturbation activity (Real et al., 2000; Leal et al., 2003; Caliman et al., 2007; Callisto et al., 2009).

The distribution of benthic populations, like that of other communities, is regulated by a combination of factors and these, interacting with each other, deter-

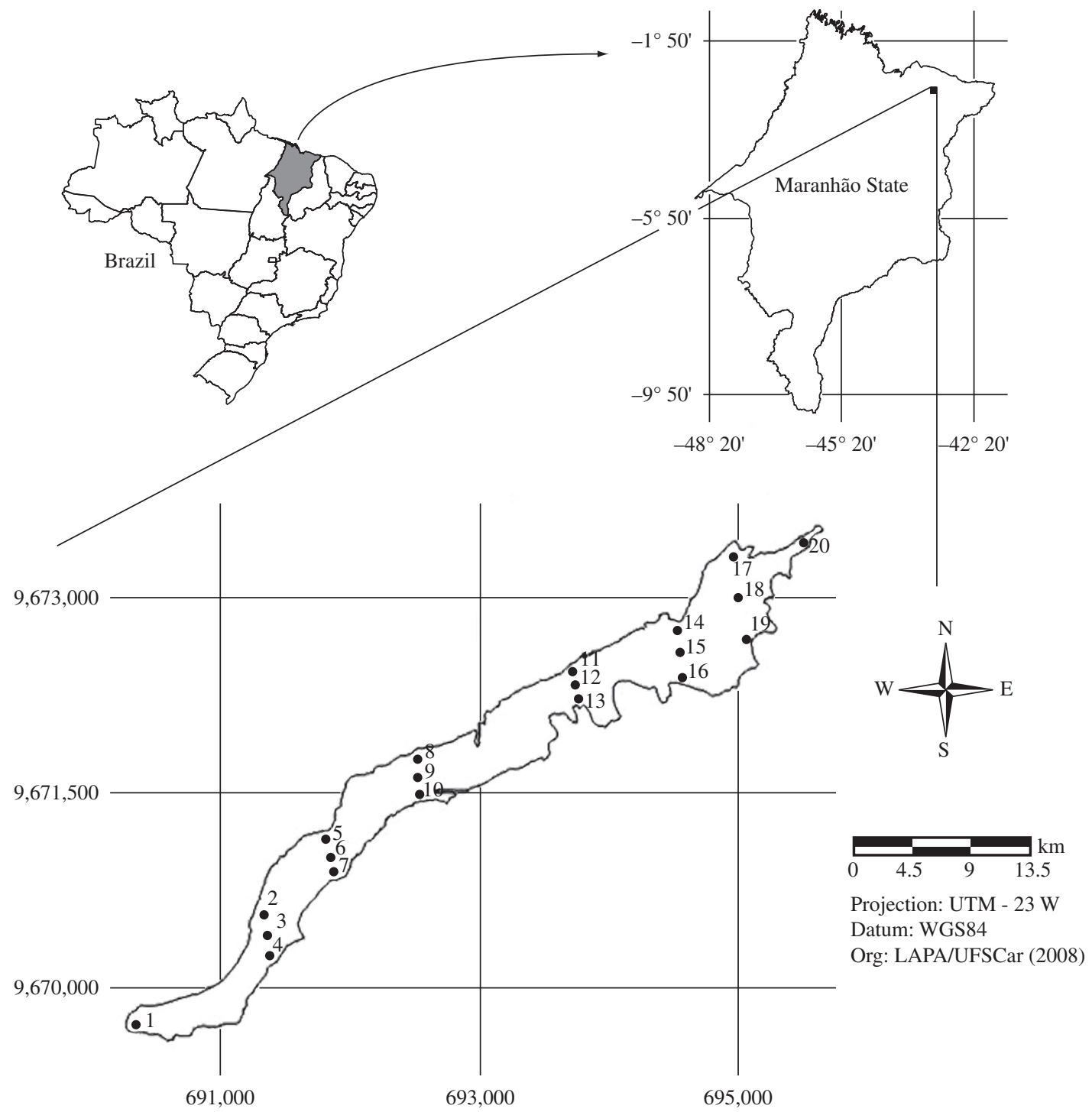

Figure 1. Location of Lake Caçó (district of Primeira Cruz, MA) in Maranhão State, Brazil and map of the Lake showing the 20 sampling points. 
mine the community structure (Saether, 1979; Warnick, 1992). Some of the most important factors are the nature of the sediment (Sanseverino and Nessimian, 1998). The depth of water and fluctuations in its level also exert great influence on the temporal changes in benthic macroinvertebrate abundance, as observed by Nessimian (1995), and Santos and Henry (2001). Coupled with the changes on water level, or determined by other isolated factors, dissolved oxygen concentration and variations in $\mathrm{pH}$ can also influence the distribution and abundance of benthic populations (Shimizu, 1981; Santos and Henry, 1997) Food availability, that can be related to lake trophic state, is one of the most important biotic factors interfering in the distribution and abundance of benthic species.

Research on the composition of benthic macroinvertebrate populations, especially those of dipteran larvae and micro-crustaceans, has long been used as an investigative tool in Palaeoecology and Palaeolimnology, since micro-fossil remains such as the head capsules of the larvae are preserved in the sediment and can be used as indicators of past climatic and lake physical and chemical conditions (Walker, 1987; Prat and Rieradevall, 1995; Massaferro et al., 2005; Verschuren and Eggermont, 2006).

The present study was proposed as a part of a broad research project entitled "Using limnological and sediment markers in lake Caçó (Northern Maranhão State, Brazil) to detect changes in the position of the Intertropical Convergence Zone during the last portion of the Quaternary period. The main objective was to characterise the current composition of benthic macroinvertebrates in Lake Caçó, and to evaluate fluctuation events of climatic and biotic variables in the past and to contribute to the knowledge of the biodiversity of Brazilian freshwater systems.

Also, considering that in South America there is little information regarding lakes near the Equator outside the Amazon region, this work constitutes one of the first reports on the benthic community of a lake in Maranhão state, Brazil. The work focused on the properties of the water and sediment of Lake Caçó and the structure of its benthic community, aiming to assess possible changes on the species composition, population density and species richness of that community as related to seasonality.

\section{Material and Methods}

\subsection{Study site}

Lake Caçó is situated in the north part of Maranhão state (Brazil), in the rural district of Primeira Cruz, about $100 \mathrm{~km}$ from the Atlantic Ocean, at coordinates $2^{\circ} 58^{\prime} \mathrm{S}$ and $43^{\circ} 25^{\prime} \mathrm{W}$. The lake was formed by a natural wall obstructing the valley cut by a river, in an ancient field of dunes at a point around $80 \mathrm{~m}$ above sea level. It is around $5 \mathrm{~km}$ long, with an average width of about $500 \mathrm{~m}$ (Figure 1). The soil surrounding Lake Caçó is a latosol covered by a mosaic type vegetation, including savannah-like forest (cerrado), palm stands and gallery forest (Ceccatine and Ledru, 1999). Dense stands of aquatic macrophytes are found, in the littoral zone. Climate data were provided by Barreirinhas Meteorological station.

\subsection{Sampling procedures}

Macroinvertebrate samples were taken at 20 sampling points with the Eckman-Birge grab $\left(225 \mathrm{~cm}^{2}\right)$, sieved through a $210 \mu \mathrm{m}$ net, and preserved in $8 \%$ formaldehyde in the field. In the laboratory, $1 \%$ rose Bengal was used to stain any specimens and all macro-invertebrates were then sorted and preserved in $70 \%$ ethanol. They were examined under an stereomicroscope, and identified to the lowest possible taxonomic level using available keys: Merritt and Cummins (1984); Roldan-Pérez (1988); Epler (1992); Trivinho-Strixino and Strixino (1995). For the oligochaetes, two keys were used: Righi (1984) and Brinkhurst and Marchese (1991). Regarding the richness of taxa, each morphotype was considered a nominal species because based on the aquatic larvae only, it was not possible to get to the species level. Densities were calculated from the total counts of organisms in the samples and were expressed as the number of individuals per square meter. Relative abundances were also calculated.

At each site the transparency of the water, $\mathrm{pH}$, electric conductivity and concentration of dissolved oxygen were measured using a Horiba multiprobe, model U-10. Total phosphorus concentrations were measured according to the method of Valderrama (1981). Lake Caçó trophic state classification was obtained using the Carlson index as modified by Toledo Jr. et al. (1983) based on total phosphorus concentrations.

\section{Results}

\subsection{Abiotic factors}

A summary of the main physical and chemical characteristics of the water of Lake Caçó is presented in Table 1. No marked changes were observed among the seasonal periods. Considering the two samplings performed in April and November (1999), in the rainy and dry periods respectively, the mean values were 5.03 and 5.53 for $\mathrm{pH}, 35.4 \mu \mathrm{S} . \mathrm{cm}^{-1}$ and $35.1 \mu \mathrm{S} . \mathrm{cm}^{-1}$ for water conductivity; $6.67 \mathrm{mg} . \mathrm{L}^{-1}$ and $6.83 \mathrm{mg} . \mathrm{L}^{-1}$ for dissolved oxygen concentrations and $29.0^{\circ} \mathrm{C}$, in both periods, for temperature. Regarding nutrients, mean values were $7.7 \mathrm{mg} . \mathrm{L}^{-1}$ and $6.7 \mathrm{mg} . \mathrm{L}^{-1}$ of total phosphorus. With such low concentrations of total phosphorus Lake Caçó was classified as an oligotrophic lake (Table 1).

\subsection{Macroinvertebrate composition and density}

In April a total of 23 taxa were recorded, 5 of which belonged to the Class Oligochaeta, 1 to the Phylum Nematoda and 20 to Insecta (Table 2). The insect larvae were classified as one Chaoboridae taxa, one Ceratopogonidae and 18 chironomids. 
Table 1. Mean values and standard deviations of $\mathrm{pH}$, electrical conductivity, dissolved oxygen, water temperature, total phosphorus and nitrogen concentrations and Trophic State Index, for Lake Caçó, Maranhão State, in April and November, 1999.

\begin{tabular}{lcc}
\hline \multicolumn{1}{c}{ Abiotic } & April/1999 & November/1999 \\
\hline $\mathrm{pH}$ & $5.03( \pm 0.54)$ & $5.53( \pm 0.51)$ \\
Electrical conductivity $\left(\mu \mathrm{S} . \mathrm{cm}^{-1}\right)$ & $35.4( \pm 1.06)$ & $35.1( \pm 0.51)$ \\
Dissolved oxygen $\left({\left.\mathrm{mg} . \mathrm{L}^{-1}\right)}^{\text {Temperature }\left({ }^{\circ} \mathrm{C}\right)}\right.$ & $6.67( \pm 0.61)$ & $6.83( \pm 0.46)$ \\
Total Phosphorus $\left(\mu \mathrm{g} . \mathrm{L}^{-1}\right)$ & $29.0( \pm 0.27)$ & $29.0( \pm 0.63)$ \\
Trophic State Index $(\mathrm{TSI})$ & $7.7( \pm 2.18)$ & $6.7( \pm 0.86)$ \\
& $25.5 \pm 4.21$ & $24.1 \pm 1.87$ \\
& $($ Oligotrophic) & \\
\hline
\end{tabular}

Table 2. Taxonomic composition, densities and relative abundances of benthic macro-invertebrates in Lake Caçó, Maranhão State, Brazil, in two sampling periods: April and November, 1999.

\begin{tabular}{|c|c|c|c|c|}
\hline \multirow[t]{2}{*}{ Taxa } & \multicolumn{2}{|c|}{ April/1999 } & \multicolumn{2}{|c|}{ November/1999 } \\
\hline & $\begin{array}{c}\text { Mean density } \\
\text { (ind. } \mathbf{m}^{-2} \text { ) } \\
\pm \text { SD } \\
\end{array}$ & $\begin{array}{c}\text { Relative } \\
\text { abundance } \\
(\%)\end{array}$ & $\begin{array}{c}\text { Mean density } \\
\text { (ind.m }^{-2} \text { ) } \\
\pm \text { SD } \\
\end{array}$ & $\begin{array}{c}\text { Relative } \\
\text { abundance } \\
(\%)\end{array}$ \\
\hline \multicolumn{5}{|l|}{ Insecta } \\
\hline \multicolumn{5}{|l|}{ Diptera } \\
\hline \multicolumn{5}{|l|}{ CHIRONOMIDAE } \\
\hline Ablabesmyia sp. & $82( \pm 148)$ & 14.45 & $102( \pm 145)$ & 6.73 \\
\hline Labrundinia sp. & $9( \pm 18)$ & 1.52 & $7( \pm 16)$ & 0.44 \\
\hline Coelotanypus sp. & $20( \pm 31)$ & 3.42 & $16( \pm 26)$ & 1.02 \\
\hline Djalmabatista sp. & $18( \pm 70)$ & 3.04 & $18( \pm 34)$ & 1.17 \\
\hline Caladomyia sp. & $27( \pm 109)$ & - & $22( \pm 44)$ & 0.44 \\
\hline Caladomyia ortoni & $9( \pm 23)$ & 4.56 & $113( \pm 170)$ & 1.46 \\
\hline Chironomus sp. & $9( \pm 18)$ & 1.52 & $56( \pm 88)$ & 3.65 \\
\hline Cladopelma sp. & $20( \pm 60)$ & 3.42 & $147( \pm 358)$ & 9.21 \\
\hline Cryptochironomus sp. & - & - & $4( \pm 14)$ & 0.29 \\
\hline Fissimentum sp. & $36( \pm 59)$ & 6.08 & $49( \pm 75)$ & 3.22 \\
\hline Goeldichironomus sp. & $2( \pm 10)$ & 0.38 & $2( \pm 10)$ & 0.15 \\
\hline Harnischai sp1. & $2( \pm 10)$ & 0.38 & $2( \pm 10)$ & 0.15 \\
\hline Nilothauma sp. & $2( \pm 10)$ & 0.38 & $2( \pm 10)$ & 0.15 \\
\hline Parachironomus sp. & $2( \pm 10)$ & 0.38 & $2( \pm 10)$ & 0.15 \\
\hline Polypedilum (Polypedilum) sp. & $20( \pm 47)$ & 3.42 & $124( \pm 171)$ & 8.19 \\
\hline Polypedilum (Asheum) sp. & - & - & $7( \pm 16)$ & 7.31 \\
\hline Tanytarsus sp. & $20( \pm 55)$ & 3.42 & $62( \pm 100)$ & 4.09 \\
\hline Tanytarsini (Gen. 1) & $9( \pm 27)$ & 1.52 & $18( \pm 44)$ & 1.17 \\
\hline \multicolumn{5}{|l|}{ CHAOBORIDAE } \\
\hline Chaoborus sp. & $147( \pm 292)$ & 25.10 & $158( \pm 246)$ & 10.38 \\
\hline \multicolumn{5}{|l|}{ CERATOPOGONIDAE } \\
\hline Gen. 1 & - & - & $20( \pm 44)$ & 1.32 \\
\hline \multicolumn{5}{|l|}{ Anellida } \\
\hline Hirudinea & - & - & $2( \pm 10)$ & 0.15 \\
\hline \multicolumn{5}{|l|}{ Oligochaeta } \\
\hline \multicolumn{5}{|l|}{ TUBIFICIDAE } \\
\hline Limnodrilus hoffmeisteri & - & - & $104( \pm 215)$ & 6.87 \\
\hline \multicolumn{5}{|l|}{ NAIDIDAE } \\
\hline Allonais sp. & - & - & $4( \pm 20)$ & 0.29 \\
\hline Bratislavia sp. & $2( \pm 10)$ & 0.38 & $2( \pm 10)$ & 0.15 \\
\hline Dero (Dero) sp. & $109( \pm 222)$ & 18.63 & $180( \pm 491)$ & 11.84 \\
\hline Dero (Aulophorus) sp. & $11( \pm 50)$ & 1.90 & $171( \pm 398)$ & 11.26 \\
\hline Homochaeta sp. & - & - & $2( \pm 10)$ & 0.15 \\
\hline Nais sp. & - & - & $27( \pm 109)$ & 1.75 \\
\hline Pristina $\mathrm{sp}$. & $18( \pm 34)$ & 3.04 & $64( \pm 116)$ & 4.24 \\
\hline Slavina sp. & $2( \pm 10)$ & 0.38 & $13( \pm 60)$ & 0.88 \\
\hline \multicolumn{5}{|l|}{ Nematoda } \\
\hline Gen. 1 & $7( \pm 16)$ & 1.14 & $27( \pm 51)$ & 1.75 \\
\hline Taxon richness & \multicolumn{2}{|c|}{23} & \multicolumn{2}{|l|}{31} \\
\hline Total mean density \pm SD (ind. $\mathrm{m}^{-2}$ ) & \multicolumn{2}{|c|}{$584( \pm 33)$} & \multicolumn{2}{|c|}{$1526( \pm 57)$} \\
\hline
\end{tabular}


Regarding the abundance of these main groups, it was found that chironomids were dominant representing 48.3 and $49.43 \%$ of the total abundance of macroinvertebrates in April and November 1999, respectively.

In November the number of taxa found was lower than in April, 23 and 31, respectively. Macroinvertebrate densities were also lower in the rainy season (April). Mean densities were $584 \pm 33$ ind. $\mathrm{m}^{-2}$ in April and 1,526 \pm 57 ind. $\mathrm{m}^{-2}$, in November 1999 (Table 3). These densities are displayed together with the monthly rainfall throughout 1999 evidencing that the sampling of material on April $12^{\text {th }}$ coincided with the month of highest rainfall in that year and that there was no rain at all in November (Figure 2). Among the main groups, Chironomidae and Oligochaeta were the most representative, both in numbers and richness of taxa at the genus level (Table 3).

Among the Chironomidae the most abundant taxa were Ablabesmyia in the samples collected in April and Cladopelma in November. Among the Oligochaeta, Dero (Dero) was dominant in both samplings.

Figure 2 presents monthly changes in the rainfall during the year 1999 and the mean density of macroinvertebrates for both sampling periods.

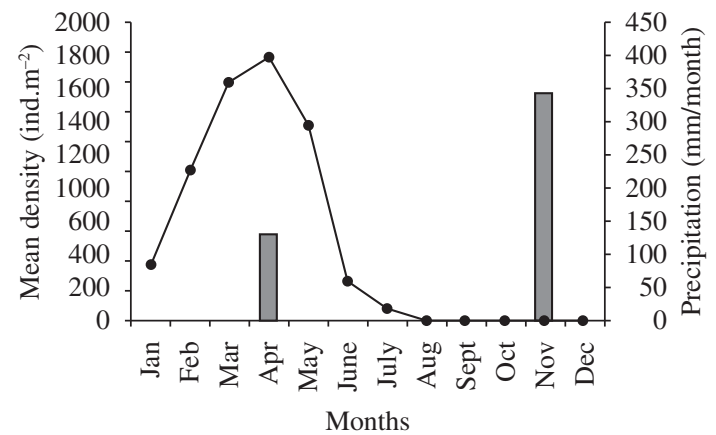

口 Mean density $\rightarrow$ Precipitation

Figure 2. Monthly changes in precipitation in Lake Caçó region, during the year 1999, and the mean density of benthic macro-invertebrates at the two sampling periods.
It can be observed that April 1999, when the first sampling survey was performed, coincided with the maximum monthly rainfall $(396.0 \mathrm{~mm})$ and the opposite in November with no rain at the time the second sampling occurred. Macroinvertebrate density changed markedly and it was more than two times higher in the dry period.

\section{Discussion}

The results indicate that lake water was acidic and had low conductivity. It also showed that the water body was quite warm and well oxygenated, and there were no marked differences in the physical and chemical characteristics of the water between the sampling periods.

Changes in the taxonomic composition and densities of the benthic macroinvertebrates in Lake Caçó, were related to seasonality, mainly driven by the differences in pluviosity. Both richness of taxa and numerical abundances were highest in the dry season (April sampling) than in the rainy summer (November). This is a recurrent pattern of benthic communities in tropical and subtropical areas, as observed by Nessimian (1995) and Callisto et al. (1998).

Organisms of the genus Dero (Naididae) were numerically predominant among the oligochaetes in both sampling periods. According to Alves and De Lucca (2000), naidids live among aquatic vegetation or in sandy sediments. Lake Caçó has both large stands of macrophytes and extensive areas with sandy sediments, which can justify their abundance.

The numerical mean densities of oligochaetes recorded in Lake Caçó in both samplings were lower than that found by Có (1979) in the oligotrophic Lobo Reservoir, SP, and those recorded for the eutrophic reservoir of Americana, SP (Pamplin et al., 2006).

Such observations corroborate the well established knowledge that oligochaete numbers increase with eutrophication of a system, but also show that other factors may be assumed to have a preponderant influence on the abundance of organisms of this group. According to Brinkhurst and Cook (1974) oligochaetes show a preference for soft substrates composed of clay and silt, rather

Table 3. Mean densities and relative abundances of the main macro-invertebrate groups in Lake Caçó benthic community in two periods: April (rainy) and November (dry), 1999.

\begin{tabular}{|c|c|c|c|c|}
\hline \multirow[t]{2}{*}{ Táxon } & \multicolumn{2}{|c|}{ April/1999 } & \multicolumn{2}{|c|}{ November/1999 } \\
\hline & $\begin{array}{l}\text { Mean density } \\
\text { (ind. } \mathbf{m}^{-2} \text { ) } \\
\pm \text { SD }\end{array}$ & $\begin{array}{c}\text { Relative } \\
\text { abundance } \\
(\%)\end{array}$ & $\begin{array}{l}\text { Mean density } \\
\text { (ind. } \mathbf{m}^{-2} \text { ) } \\
\pm \mathrm{SD}\end{array}$ & $\begin{array}{c}\text { Relative } \\
\text { abundance } \\
(\%)\end{array}$ \\
\hline Chironomidae & $287( \pm 148)$ & 49.43 & $733( \pm 125)$ & 48.37 \\
\hline Chaoboridae & $140( \pm 292)$ & 25.10 & $158( \pm 246)$ & 10.50 \\
\hline Ceratopogonidae & - & - & $20( \pm 44)$ & 1.33 \\
\hline Oligochaeta & $142( \pm 87)$ & 24.33 & $569( \pm 235)$ & 37.87 \\
\hline Hirudínea & - & - & $2( \pm 10)$ & 0.15 \\
\hline Nematoda & $7( \pm 16)$ & 1.14 & $27( \pm 51)$ & 1.78 \\
\hline
\end{tabular}


than sand. Regarding the low densities of benthic macroinvertebrates in Lake Caçó it is probable that the low amount of organic matter in the sediment (Lucca, 2002) was the determinant factor, since the substrate composition is heterogeneous.

Dipteran insects represented over half of the macroinvertebrate population in Lake Caçó, in both sampling periods. Both natural and artificial lakes provide a wide spectrum of habitats for aquatic insects, so that they form 10 to $90 \%$ of all benthic organisms in these water bodies. Thus, in São José dos Cordeiros Dam, PB, chironomids represented, as a mean, $89 \%$ of the benthic macroinvertebrates; Brito-Júnior et al. (2005); in Lake Monte Alegre, Ribeirão Preto district, SP, Chironomidae contributed with more than $50 \%$ of the whole benthic community (Cleto-Filho and Arcifa, 2006); in Jurumirim reservoir, Paranapanema river basin, this group represented $50 \%$ of benthic macroinvertebrates (Jorcin and Nogueira, 2008).

The community richness, at genus level, found in Lake Caçó (23 taxa) is not very high compared with other lentic natural systems. At the same taxonomic level (genus) in Atlantic Forest lakes in Rio Doce Valley (MG) Marques et al. (1999) recorded 33 taxa, and in Jurumirim Reservoir, Parapanema River (SP) Jorcin and Nogueira (2008) reported 48 taxa. Improving sampling frequency and taxonomical analysis resolution can considerably increase the richness, as evidenced in the work of Siqueira et al. (2007) which found 71 species/morphospecies in the small Fazzari stream, São Carlos, SP.

Chironomids were numerically dominant among the insects, contributing around $50 \%$ of the whole fauna, in both sampling periods. Certain species of this family are nearly always dominant in both lotic and lentic water systems, owing to their tolerance of extreme conditions, such as hypoxia, and their strongly competitive nature. This has pointed out in studies performed in several types of habitats and aquatic ecosystems in Brazil (Brito-Júnior, 2005; Sanseverino and Nessimian, 2001). The results of Lake Caçó can be compared with average chironomid densities of 661 ind. $\mathrm{m}^{-2}$, observed by Rodrigues (1997) in a sweep of different sites on the Beija-Flor reservoir, and 370 ind. $\mathrm{m}^{-2}$ recorded by Alves (1998) in Lake Diogo, both water-bodies being located in the Jataí Ecological Reserve (São Paulo State, Brazil) and classified as mesotrophic water bodies according to the TSI of Carlson (1977) as modified by Toledo Jr. et al. (1983).

In Lake Caçó (MA), chironomid densities were significantly higher than those cited above, despite the oligotrophic nature of the lake. An effective mechanism that can control the density of any benthic population is the pressure of predation by fish species and also by predatory invertebrates (Margalef, 1983). Yet, there is no information on fish abundances for Lake Caçó. The overall numerical density and richness of the benthic invertebrates recorded in this lake in April and November 1999 were influenced largely by precipitation. During the dry period (November), the density over the lake as a whole was about three times that in the rainy period (April) and richness was also significantly higher. It is possible that a greater availability of food and reduced turbulence in that season were responsible for the higher richness of taxa in the benthic community, what was also observed by Callisto et al., 2002 regarding the benthic community in water bodies in the National Park of Cerra do Cipó (MG) and National Park of Bocaina (RJ). Similar patterns of temporal changes in benthic macroinvertebrates occur in other tropical lakes despite latitudes and trophic state, as evidenced by Lucca (2006) in four lakes of middle Rio Doce basin (MG) and by Pamplin and Rocha (2007) in Ponte Nova reservoir (SP).

The dominance of chironomids in the benthos of Lake Caçó makes them a possible tool for additional interpretations regarding paleoenvironmental conditions. Chironomids are among the invertebrates whose remains are often found as microfossils in the lake sediment, providing a past record of lake conditions. The head capsules of their exuviae frequently remain in the sediment if there are adequate conditions for preservation. The taxonomic identification of these structures in the sediment cores of the lake and its comparison with recent chironomid species can be of relevance for reconstruction of paleoenvironmental conditions Quinlan and Smol (2001), since sediment cores of Lake Caçó were collected (Jacob et al., 2007a; Jacob et al., 2007b).

Summoning up, the data collected in Lake Caçó in April and November, 1999, show that the alternation of wet and dry seasons acts as the principal factor behind the changes observed in limnological conditions and the benthic community composition, corroborating the hypothesis that at these low latitude tropical lakes the Intertropical Convergence Zone (ZCIT) seasonal displacement and related precipitation pattern is the main driving force.

Acknowledgements - To the São Paulo State Research Aid Foundation (FAPESP) for the grant, number 98/776-8. This project is an integral part of the International Collaboration Programme established between the Brazilian National Research Board Council, CNPq, and the French Institut de Recherche pour le Développement (IRD, formerly ORSTOM), whose financial support is also acknowledged.

\section{References}

ALVES, RG., 1998. Dinâmica Espaço-Temporal dos macroinvertebrados bentônicos de uma lagoa marginal de drenagem. São Carlos: Universidade Federal de São Carlos. 120 p. [Tese de Doutorado]

ALVES, RG. and LUCCA, JV., 2000. Oligochaeta (Annelida: Clitellata) como indicador de poluição orgânica em dois córregos pertencentes à Bacia do Ribeirão do Ouro Araraquara (São Paulo, Brasil). Brazilian Journal of Ecology, vol. 4, no. 1-2, p. 112-117.

BRINKHURST, RO. and COOK, DG., 1974. Aquatic earthworms (Annelida: Oligochaeta). In HART Jr., CW. and FULLER, SLH. (Eds.). Pollution ecology of freshwater invertebrates. New York: Academic Press. p. 143-156. 
BRINKHURST, RO. and MARCHESE, MR., 1991. Guia para la identificacion de Oligoquetos acuáticos continentales de Sudy Centroamerica. Santo Tomé: Associación de Ciencias Naturales del Litoral. 207 p.

BRITO Jr., L., ABILIO, FFP., WATANABE, T., 2005. Aquatic insect of São José dos Cordeiros dam (Paraiban semi-arid) with emphasis in Chironomidade. Entomologia Vectores, vol. 12, no. 2, p. 149-157.

CALIMAN, A., LEAL, JJF., ESTEVES, FA., CARNEIRO, LS., BOZELLI, RL. and FARJALLA, VF., 2007. Functional bioturbator diversity enhances benthic-pelagic processes and properties inexperimental microcosms. Jounal of the North American Bentological Society, no. 26, p. 450-459.

CALLISTO, M. and ESTEVES, FA., 1998. Biomonitoramento da macrofauna bentônica de Chironomidae (Diptera) em dois igarapés amazônicos sob influência das atividades de mineração de bauxita. In NESSIMIAN, JL. and CARVALHO, AL. (Eds.). Ecologia de Insetos Aquáticos. Rio de Janeiro: UFRJ. p. 2999-309 (Série Oecologia Brasiliensis, 5).

CALlisto, M., FERREIRA, W., MORENO, P., GOULART, MDC. and PETRUCIO, M., 2002. Aplicação de um protocolo de avaliação rápida da diversidade de habitats em atividades de ensino e pesquisa (MG-RJ). Acta Limnologica Brasiliensia, vol. 14, no. 1, p. 91-98.

CALLISTO, M., LEAL, JJF., FIGUEREDO-BARROS, MP., MORENO, P. and ESTEVES, FA., 2009. Effect of bioturbation by Chironomus on nutrient fluxes in an urban eutrophic reservoir. In Proceedings of the 7 International Symposium on Ecohydraulics. Concepcion: Universidad de Concepcion. p. 76-86. (v. 1)

CECCATINE, G. and LEDRU, MP., 1999. Panorama Botânico da Lagoa Caçó. In Resumos do I Workshop do Projeto Maranhão. Rio de Janeiro. 7 p.

CLETO FILHO, SEM. and ARCIFA, MS., 2006. Horizontal distribution and temporal variation of the zoobenthos of a tropical Brazilian lake. Acta Limnologica Brasiliensia, vol. 18, no. 4, p. $407-421$.

CO, LM., 1979. Distribuição de Oligochaeta na Represa do Lobo (Estado de São Paulo). São Carlos: Universidade Federal de São Carlos. 169 p. [Dissertação de Mestrado]

DAVANSO, RCS. and HENRY, R., 2007. Composition and abundance of Chironomidae and Ephemeroptera larvae in a lateral lake in the mouth zone of Paranapanema River into Jurumirim Reservoir (State of São Paulo). Acta Limnologica Brasiliensia, vol. 19, no. 2, p. 131-142.

EPLER, JH., 1992. Identification manual for the larval Chironomidae (Diptera) of Florida. Florida: Department of Environmental Regulation. 427 p.

FIDELIS, L., NESSIMIAN, JL. and HAMADA, N., 2008. Distribuição espacial de insetos aquáticos em igarapés de pequena ordem na Amazônia Central. Acta Amazonica, vol. 38, no. 1, p. 127-134.

FUKUHARA, H. and SAKAMOTO, M., 1988. Ecological significance of bioturbation of zoobenthos community release from bottom sediments in shallow eutrophic lake. Archiv fur Hydrobiologie, vol. 113, no. 3, p. 425-445.

GARDNER, WS., NALEPA, TF., SLAVENS, DR. and LAIRD, GA., 1983. Patters and rates of nitrogen release by benthic Chironomidae and Oligochaeta. Canadian Journal of Fisheries and Aquatic Sciences, vol. 40, no. 3, p. 259-266.
GONÇALVES, JJF., GRACA, M. and CALLISTO, M., 2007. Litter decomposition in a Cerrado - savannah stream is retarded by leaf toughness, low water nutrient levels and lack of shredders. Freshwater Biology, vol. 52, no. 8, p. 1440-1451.

HENRY, R. and SANTOS, CM., 2008. Importance of excretion by Chironomus larvae to internal loads of nitrogen and phosphorus in a small eutrophic urban reservoir. Revista Brasileira de Biologia = Brazilian Journal of Biology, vol. 68, no. 2, p. 349-357.

JACKSON, JK., and SWEENEY, BW., 1995. Egg and larval development times for 35 species of tropical stream insects from Costa Rica. Journal of the North American Benthological Society, vol. 14, no. 1, p. 115-130.

JACOB, J., DISNAR, JR., BOUSSAFIR, M., SPADANOALBUQUERQUE, AL., SIFEDDINE, A. and TURCQ, B. 2007a. Contrasted distribution of triterpene derivatives in the sediments of Lake Caçó reflect paleoenvironmental changes during the last 20,000 yrs in NE Brazil. Organic Geochemistry, vol. 38, no. 2, p. 180-197.

JACOB, J., HUANG, Y., DISNAR, JR., SIFEDDINE, MB., SPADANO-ALBUQUERQUE, AL. and TURQC, B. 2007b. Paleohydrological changes during the last deglaciation in Northern Brazil. Quaternary Science Reviews, vol. 26, no. 7-8, p. 1004-1015.

JORCIN, A. and NOGUEIRA, MG., 2008. Benthic macroinvertebrates in the Paranapanema reservoir cascade (southeast Brazil). Revista Brasileira de Biologia = Brazilian Journal of Biology, vol. 68, (suppl. 4), p. 1013-1024.

LEAL, JJF., ENRICH-PRAST, A., ESTEVES, FA. and FARJALLA, VF., 2003. Effect of Campsurus notatus on NH4, DOC fluxes, O2 uptake and bacterioplankton production in experimental microcosms with sediment-water interface of an Amazonian lake impacted by bauxte tailings. International Review of Hydrobiology, vol. 88, no. 2, p. 167-178.

LUCCA, JV., 2002. Composição, distribuição e abundância dos macroinvertebrados bentônicos da lagoa do Caçó (MA). São Carlos: Universidade de São Paulo. 123 p. [Dissertação de Mestrado]

-, 2006. Caracterização limnológica e análise da comunidade bentônica sujeita a invasão por espécies exóticas, em lagos do Vale do Rio Doce, MG, Brasil. São Carlos: Universidade de São Paulo. 215 p. [Tese de Doutorado].

MARQUES, MGSM., FERREIRA, RL. and BARBOSA, FAR., 1999. A comunidade de macroinvertebrados aquáticos e características limnológicas das lagoas Carioca e daBarra, Parque Estadual do Rio Doce, MG. Revista Brasileira de Biologia = Brazilian Journal of Biology, vol. 59, no. 2, p. 203-210.

MARGALEF, R., 1983. Limnologia. Barcelona: Ediciones Omega. 1009 p.

MASSAFERRO, J., BROOKS, SJ. and HABERLE, SG., 2005. The dynamics of chironomid assemblages and vegetation during the Late Quaternary at Laguna Facil, Chonos Archipelago, southern Chile. Quaternary Science Reviews, vol. 24, no. 23-24, p. $2510-2522$.

MERRIT, R. and CUMMINS, K., 1984. An introduction to the aquatic insects of North America. 2 ed. Dubuque: Kendall-Hunt Publishing. $722 \mathrm{p}$.

MORENO, P. and CALLISTO, M., 2006. Benthic macroinvertebrates in the watershed of an urban reservoir in southeastern Brazil. Hydrobiologia, vol. 560, no. 1, p. 311-321.

NESSIMIAN, JL., 1995. Abundância e biomassa de macroinvertebrados bentônicos em um brejo de dunas do litoral 
do Estado do Rio de Janeiro. Revista Brasileira de Biologia = Brazilian Journal of Biology, vol. 55, no. 4, p. 661-683.

NESSIMIAN, JL. and OLIVEIRA, ALH., 2005. Colonização do litter de Eleocharis sellowiana por larvas de Chironomidae (Diptera) em um brejo no litoral do Estado do Rio de Janeiro. Zoologia y Vectores, vol. 12, no. 2, p. 159-172.

PAMPLIN, PAZ., ALMEIDA, TCM., ROCHA, O., 2006. Composition and distribution of bentic macroinvertebrates in Americana Reservoir, SP, Brasil. Acta Limnologica Brasiliensia, vol. 18, no. 2, p. 121-132.

PAMPLIN, PAZ. and ROCHA, O., 2007. Temporal and bathymetric distribution of benthic macroinvertebrates in the Ponte Nova Reservoir, Tietê River (São Paulo, Brazil). Acta Limnologica Brasiliensia, vol. 19, no. 4, p. 439-452.

PARSONS, M. and NORRIS, RH., 1996. The effect of habitatspecific samplings on biological assessment of water quality using a predictive model. Freshwater Biology, vol. 36, no. 2, p. $419-436$

PELEGRÍ, SP. and BLACKBURN, TH., 1996. Nitrogen cycling in lake sediment bioturbated by Chironomus plumosus larvae, under different degrees of oxygenation. Hydrobiologia, vol. 325, no. 3, p. 231-238.

PRAT, N. and RIERADEVALL, M., 1995. Life cycle and production of Chironomidae (Diptera) from Lake Banyoles (NE Spain). Freshwater Biology, vol. 33, no. 3, p. 511-524.

QUINLAN, R. and SMOL, JP., 2001. Setting minimum head capsule abundance and taxa deletion criteria in chirnomid-based inference moldels. Journal of Paleolimnology, vol. 26, no. 3, p. $327-342$

REAL, M., RIERADEVALL, M. and PRAT, N., 2000. Chironomus species (Diptera: Chironomidae) in the profundal benthos of Spanish reservoirs and lakes: factors affecting distribution patters. Freshwater Biology, vol. 43, no. 1, p. 1-18.

RIGHI, G., 1984. Oligochaeta. Brasília: CNPQ. 48 p. (Série Manual de Identificação de Invertebrados Límnicos do Brasil)

RODRIGUES, MHS., 1997. Estudo da fauna de Chironomidae (Diptera) do sedimento na Represa do Beija-Flor, na Estação Ecológica de Jataí, Luíz Antonio - SP. São Carlos: Universidade Federal de São Carlos. 75 p. [Dissertação Mestrado]

ROLDAN-PÉRES, G., 1988. Guía para el estudo de los macroinvertebrados acuáticos del Departamento de Antioquia. Bogotá: Universidade de Antioquia. 217 p.

SAETHER, OA., 1979. Chironomid communities as water quality indicators. Holartic Ecology, vol. 2, no. 2, p. 65-74.

SCHMAH, A., 1993. Variation among fossil chironomid assemblages in surficial sediments Bodensee-Untersee (SWGermany): implication for paleolimnological interpretation. Journal of Paleolimnology, vol. 9, no. 2, p. 99-108.

SANSEVERINO, AM., NESSIMIAN, JL. and OLIVEIRA, ALH., 1998. A fauna de Chironomidae (Díptera) em diferentes biótopos aquáticos na Serra do Subaio (Teresópolis, RJ). In NESSIMIAN, JL. and CARVALHO, AL. (Eds). Ecologia de insetos aquáticos. Rio de Janeiro: UFRJ. p. 253-263. (Séries Oecologia Brasilenses, 5)

SANSEVERINO, AM. and NESSIMIAN, JL., 2001. Hábitats de larvas de Chironomidae (Insecta, Diptera) em riachos de Mata Atlântica no Estado do Rio de Janeiro. Acta Limnologica Brasiliensia, vol. 13, no. 1, p. 29-38.

SANTOS, CM. and HENRY, R., 1997. Análise da densidade e diversidade da fauna bentônica da Represa de Jurumirim (Rio Paranapanema- SP) em dois períodos do ano. In Anais do 8 Seminário Regional de Ecologia. São Carlos: Universidade Federal de São Carlos. p. 151-162. (vol. 8)

-, 2001. Composição, distribuição e abundância de Chironomidae (Diptera, Insecta) na Represa de Jurumirim (Rio Paranapanema SP). Acta Limnologica Brasiliensia, vol. 13, no. 2, p. 99-115.

SHIMIZU, GY., 1981. Represa de Americana: um estudo de distribuição batimetrica da fauna bentônica. São Paulo: Universidade de São Paulo. [Tese de Doutorado]

SIQUEIRA, T., OLIVEIRA-ROQUE, F. and TRIVINHOSTRIXINO, S., 2007. Species richness, abundance, and body size relationships from a neotropical chironomid assemblage: Looking for patterns. Basic and Applied Ecology, no. 9, p. 606-612.

STRIXINO, G. and TRIVINHO-STRIXINO, S., 1980. Bottom macroinvertebrates od Lobo reservoir (State of Sao paulo, Brazil): I. Distribution and abundance of chironomids and chaoboris (Diptera). Tropical Ecology, vol. 21, no. 1, p. 16-23.

-, 1998. Povoamento de Chironomidae (Diptera) em lagos artificiais In NESSIMIAN, JL. and CARVALHO, AL. (Eds). Ecologia de insetos aquáticos. Rio de Janeiro: UFRJ. p. 141-154. (Séries Oecologia Brasilenses, 5)

TOLEDO Jr., AP., TALARICO, M., CHINEZ, SJ. and AGUDO, EG., 1983. A aplicação de modelos simplificados para a avaliação do processo da eutrofização em lagos e reservatórios tropicais. In Anais do 12 Congresso Brasileiro de Engenharia Sanitária e Ambiental. Camboriú: DENG.

TRIVINHO-STRIXINO, S. and STRIXINO. G., 1995. Larvas de Chironomidae (Diptera do Estado de São Paulo): guia de identificação de diagnose dos gêneros. São Carlos: EdUFSCar. $229 \mathrm{p}$.

VALDERRAMA, JC., 1981. The simultaneous analysis of total nitrogen and phosphorus in natural waters. Marine Chemistry, vol. 10, no. 2, p. 109-122.

VERSCHUREN, D. and EGGERMONT, H., 2006. Quaternary paleoecology of aquatic Diptera in tropical and southern Hemisphere regions, with special reference to the Chironomidae. Quaternary Science Reviews, vol. 25, no. 15-16, p. 1926-1947.

WALKER, IR., 1987. Chironomidae (Diptera) in Paleoecology. Quaternary Science Reviews, vol. 6, no. 1, p. 29-40.

WARNICK, WF., 1992. The effect of trophic/contaminant interactions on chironomid community structure and succession (Diptera: Chironomidae). Netherland Journal Aquatic Ecology, vol. 26 , no. $2-4$, p. $563-575$. 